\title{
The Effect of Teacher Professional Development in Raising the Quality of Teaching (Pilot Research)
}

\author{
Arberore Bicaj, PhD Candidate \\ University of Prishtina "Hasan Prishtina", Agim Ramadani str. 10000 Prishtina, Kosovo \\ Email: arberore6@hotmail.com \\ Dr. Tomi Treska
}

European University of Tirana, Bulevardi “Gjergj Fishta”nd.70 H1, 1023 Tirana, Albania

Email: tomi.treska@uet.edu.al

Doi:10.5901/ajis.2014.v3n6p369

\begin{abstract}
The role and importance of life-long learning as part of a teacher's qualification is unquestionable, in particular in terms of the teachers' personal and professional development, as well as in promoting the school image, improving teacher performance, and enhancing the quality of teaching. Kosovo is still going through a process of transition. Every day new reforms are being introduced. Most of these efforts, such as the new competence based Curriculum Framework, focus in developing education in general; others are more specific and aim, for instance, at improving teachers' professional development. The latter is a very sensitive and critically important area that requires attention and commitment. In this regard, the Ministry of Education, Science and Technology, in collaboration with various non-profit, governmental and international organizations, have organized numerous professional trainings for teachers in Kosovo. The programme of teacher training sessions, offered in partnership with the University of Pristina, is called the In-Service Teacher Qualification programme1. In this paper we have analyzed the training programmes offered to the teachers of Kosova, surveying the effects and benefits of professional advancement on creating new knowledge and improving the quality of teaching. The survey results have verified the main hypothesis regarding the effect of professional development in raising the quality of teaching, but they have not verified completely auxiliary hypothesis which views (considers) the program as a mechanism to meet the professional development needs of teachers.
\end{abstract}

Keywords: professional development, quality of teaching, teacher qualification, lifelong learning

\section{Introduction}

Teaching is going through a momentum of great transformations in many countries. The dynamic changes in the field of education are encouraging most of the teachers to work more collaboratively in order to respond effectively to those changes and achieve the highest standards of performance.

The pressures and demands of learning new skills of teamwork, thinking on a higher level, and successful use of new information technologies have been a kind of appeal to new teaching styles (Hargreaves, 2000, p. 151). As a result, a new way of teaching and professional development of teachers was required.

Tired teachers with unsatisfactory payments were imposed to a situation where they need to learn and implement standards of teaching and detailed curriculum objectives. They were aware of the changes they needed to undertake, and also aware that they should be subject to changes in the professional development practice. All these trends and pressures were an important factor that spurred teachers to reassess their professionalism and make the right decisions for the best professional development in order to advance their aimed goals with students (Hargreaves, 2000, p. 151152).

Furthermore, systems that invest in professional capital admit that spending on education is an investment in human capital development from early childhood to adulthood. Yet, investments must be made even if they are intended to make a turn on education (Hargreaves \& Fullan, 2012).

1 The In - Service Teacher Qualification programme, is the same programme as the In - Service Teacher Training programme that has been used in other papers 
In Kosovo, during this last decade in particular, increased efforts took place towards improved teacher professional development. Ministry of Education, Science and Technology (MEST), is committed to improving the quality of education in a structure approach, including developing new strategies and educational policies, curricular reforms, publication of new textbooks, and teacher professional development. In this context, particular importance has been given to the professional development of teachers, in full awareness that the teachers bring changes directly to the classrooms making students part of these changes.

As part of these efforts, the National Council for Teacher Licensing (NCTL), established in January 2009, initiated the process of building a teacher licensing system, as the best way to ensure that teaching methodologies are constantly improved and that they serve to implement the new school curriculum. The National Council for Teacher Licensing drafted and adopted two administrative instructions, one for the accreditation of in-service training programmes and the other one for teacher licensing. In there, teacher licensing is conceived as a system intricately linked to the salary system and salary increases, and to teacher professional development efforts, work experience, teacher qualifications, and teacher performance evaluation (Cakaj, 2011, p. 18).

Furthermore, since 2006, a programme, called In - Service Teacher Qualification programme, that lead teachers to higher qualifications, is functioning. Such programme, would have to differ from other in-service teacher training programmes organized by the non - governmental organizations, therefore would have to be offered in institutional level, and it should belong to formal education (Bicaj \& Berisha, 2013, p. 207).

Purpose of the paper - The purpose of this paper is to conduct a research to the available teacher professional development programmes and look into teachers' perspectives and reflection on these programmes, as well as the $I n-$ Service Teacher Qualification programme that has been attended by most of the teachers in Kosovo. In other words, the paper aims to see what is the difference between training programmes and the In - Service Teacher Qualification programme, and to reflect on the impact professional development is having in increasing the quality of teaching.

\section{Literature Review}

The In-service Teacher Qualification programme is taking place under the framework of a life-long learning approach.

Lifelong education has a diversified and challenging historical development. Based on the literature, the origin of lifelong education is differently discussed. Often it is thought that the origin of Education throughout life dates from the 70s, when it was used for the first time by international organizations, such as United Nations Educational, Scientific and Cultural Organisation (UNESCO) and the Organisation for Economic Co-operation and Development (OECD). On the other hand, Hawes, asserts that the concept of 'lifelong learning' or 'lifelong education' is as old as civilization itself. He notes that, although the name may be new, people have long been aware that they must learn to survive (Kheng, 2006, p. 4).

In the 60s, lifelong education was linked in complex ways to changes in the practices of teachers and students (Hager \& Haliday, 2006, p. 15). At the same time, the author Dragomir Filipovic, in his book "Obrazovanje odraslih u teoriji i praksi" (Adult education theory and praxis) says that to know the history of adult education, one should be known first the history of pedagogy, and the educational development, before the creation of the science of pedagogy. Furthermore, Filipovic presents the development of the science of pedagogy in the XVIII century, while considering andragogy as a scientific discipline of education in the XX century (Filipovic, 1967, p. 28).

Many researchers have addressed the lifelong learning; most notable among them is the contribution of Malcolm S. Knowles, known as the father of andragogy, who brought andragogy (the general science of adult education) to America, in the 70s. This was the time when it was believed that adults learn differently from children (Knowles, Holton III, \& Swanson, 2007, p. 1).

In the XXI century, the motivation for lifelong learning and the ability to participate productively and responsibly in a diverse society is a crucial component for the success of teachers at their work (Mayhew, Wolniak, \& Pascarella, 2007). The educational psychologists recognize that learning and development are inside and outside of the school, within family, at work and in other contexts. Additionally, they have regarded learning and development as a lifelong activity. (Smith \& Pourchot, 1998 p. 5).

To no surprise, in March 2000, the Lisbon European Council reaffirmed the importance of employment, training and upgrading of teachers and coaches for the development of lifelong learning (Kassworm \& Hemmingsen, 2006). Mentioning Adult Education as a component of Lifelong Education, we consider adults and their experience as part of professional development, and in this context the increasing of performance in school.

To switch from the international perspective to the situation in our country we will look briefly at the works and 
approach of some Albanian authors to see the impact of teacher professional development in improving quality of teaching and learning in the classroom.

Valier Peshkëpia, in his book "Teaching learning and its relations with European integration" sees the school as an educational institution, which aims not only at reproduction or repetition of knowledge, but works to enable individuals to acquire the information, to process it and to be able to operate and solve various problems (Peshkëpia, 2012, p. 19-20). To master this whole process, teachers need to be educated and developed continuously, which means to be life-long learners.

Among the Albanian readership and educators, the concept of Adult Education was mentioned for the first time during the Renaissance times, when schools in Albanian were opened not only for children, but also for adults. School was considered then as a priority mechanism for the education of the population. The issue of professional training of teachers was among the issues addressed at the Elbasan Education Congress, 1909. In the town of Vlore, schools organized short courses for pedagogical training of teachers (Koliqi, 2013, p. 223-225).

From the study of literature, it is clear that despite the differing opinions regarding the history of lifelong education, the importance of professional development of teachers is one of the key elements of Lifelong learning and adult education that affects teachers' work performance. In a way, unlike in ancient times, when learning was referred to as a necessity for survival, in more modern times terms "lifelong education" and "Adult Education" have increasingly been associated with quality of teaching and changing classrooms teaching and learning. But the question arises, whether there are sufficient programs available for professional development, or if is considered any form of professional development, necessary and important for each age and category of teachers?

\subsection{Teacher professional development (training) at the international level}

Today, at a time of rapid and continuous changes, one of the key conditions for achieving a quality teaching process is a professionally trained teacher. This way, the focus of the teaching profession is not simply to mediate in the process of knowledge acquisition, but the teacher to support students in the learning process, and based on their age, to help them take responsibility for their own behaviour and to make them independent. Therefore, considering the complex role of the teacher in modern schools, teachers should be trained, facing new challenges and tasks for the full implementation of the responsibilities in the classroom (V. Zuljan \& Vogrinc, 2011, p. 7).

Professional development aims to train teachers after completing pre-service studies, by continuously developing knowledge and skills of teachers.

Almost all European countries provide opportunities for teachers to have access to various forms of Professional development while working. In some countries, professional training is compulsory, whereas in others it is not (Klashnja, 2006, p. 31).

In various countries, the responsibility to organize training programmes for teachers is differently divided between the central, regional, local or school levels. For example, the Ministry is responsible for this issue in Finland, whereas employees play a role in designing training programs. In Romania, teacher training is offered mainly by non-governmental organizations, but also by training centers within universities, educational colleges and vocational training centers. In Slovenia and Lithuania, there was a decentralization of professional development in 1998. School directors were responsible for further professional training, in line with national goals. In Holland, training programmes were not in accordance with the needs of teachers, but with needs of the institutions. Therefore, the budget for vocational training was transferred from high-level institutions to schools, so that schools can make the selection of training programmes for their teaching staff. Also, in Sweden and in the UK, schools turned into institutions for professional training of teachers. Consequently, because of no uniform policy for vocational training at the state level, in Bosnia and Herzegovina, professional development remained under the authority of the regions (Klashnja, 2006, p. 32-34).

In some countries, because of the risk of quality of programmes offered, and because of the lack of control for many training providers, accreditation systems for professional development programmes are established. This has happened in the UK, Portugal, Romania, Hungary, Moldova, Serbia and Kosovo. According to the law, each module of the professional development programme has a number of credits for that module (Klashnja, 2006, p. 34). Teachers are required to accumulate a given number of credits (example, 20 credits points a year in Kosovo). Any programme that does not fall under this scheme and is not accredited, will not count for teacher licensing. The reports of some East European countries emphasized that the various non-governmental organizations are implementing professional development programmes. In this case, these programmes cannot be accredited, because they are not valid for the career development of teachers (Klashnja, 2006, p. 35). 
Teachers, as key persons of education reform, should be always ready for changes. Therefore, a general system of teacher professional development, as a continuous process, is necessary to be established, including a wider area, among other and basic studies, along with practice and internship, monitoring and evaluation system of student's work, as well as the professional training while working and professional development system for teachers (Klashnja, p. 20). But, this paper is focused only on the last two issues (above mentioned). According to the the authors in the book, professional training on-the-job (while working), is aimed to improve existing practice and not achieving higher qualifications; on the other hand, professional training leading to the advancement and promotion of qualifications, is developed in an institutional form, for example as part of postgraduate studies (Klashnja, 2006, p. 31).

Almost uniquely in the region and wider, in Kosovo, the In - Service Teacher Qualification programme, specially thought and designed by the University of Prishtina and the Ministry of Education experts, serves to lead to upgraded teacher qualifications from the previous two years' teacher training qualification of the former Higher Pedagogical School (HPS), to a four year bachelor degree as a class or a subject teacher.

\subsection{Teacher professional development (training) in Kosovo}

Kosovo developed an in-service professional training in accordance with the legal framework and other supporting policies for teacher training (Salihu, 2006, p. 53).

The In - Service Teacher Qualification programme was a good opportunity for advancing existing qualifications of teachers in Kosovo, parallel with gaining new knowledge, improving existing practice and increasing performance in the classroom.

About the functioning of the In - Service Teacher Qualification programme: The Ministry of Education, Science and Technology (MEST), University of Prishtina (UP) and the Canadian program (KEDP), signed an agreement in 2006, for the functioning of the programme in the four centers of the Faculty of Education, in Prishtina, Gjakova, Gjilan and Prizren. Furthermore, the Advance of Qualification programme was operating under the decisions of the governing council and the internal regulation agreed by the Statute of the University of Prishtina and MEST guidelines, and was one of the first programmes functioning the lifelong learning of teachers in Kosovo (Bicaj \& Berisha, 2013, p. 207). The students of the programme would receive the title Bachelor of Education, and at the end of the programme, they would have to collect 240 credits (ECTS).

Since than, despite the challenges, the programme managed to survive with success, thanks to the commitment and work of academic staff and management of the programme, and due to the enthusiasm of Kosovo teachers.

In June 2010, MEST and UP, signed a cooperation agreement for the continuation of the programme. The aim was the qualification equivalence and promotion of qualified Kosova teachers, and in the meantime complementing the Bologna Process objectives.

Today, the program continues with 10 programmes of study and with a large number of students. The following programmes are offered (Bicaj \& Kotori, 2013, p. 2):

- Preschool education programme,

- Primary education programme,

- Mathematics - Informatics programme,

- Technology - Informatics programme,

- Albanian Language and Literature programme,

- English Language programme,

- Physics - Chemistry programme,

- Biology - Chemistry programme,

- History - Civic education programme,

- Geography - Civic education programme.

On the other hand, in terms of professional development of teachers, the Ministry of Education, Science and Technology (MEST), has accredited 22 teacher professional development providers with a total of 43 teacher training programmes (Cakaj, 2011). According to the National Council for Teacher Licensing document of the MEST, after 2011, there are 37 other programmes accredited.

\subsection{Programmes for professional development of teachers}

In Kosovo, there was no progress made in almost any aspect of education sector, primarily because of the prosecution by 
the Serbian state and isolation from international trends and developments in education of the '90s. The war of 1999 marked the culmination of the difficulties facing the education sector in Albanian in Kosovo. As a result, there was lack of any exchange with any international practices and expertise and a total lack of any teacher professional development. There was a critical need for organizing teacher professional development activities with an aim to introduce innovations and to improve the teaching and learning process (EU EDUCATION SWap, 2011, p. 8 - 9).

In the beginning of 2000 there was a myriad of small teacher training providers with not more than one minor intervention with a limited scope and lacking any sustainability. This is when the then international administration headed by Dr. Michael Daxner introduced the so-called concept of lead agencies that would serve to coordinate effort in given sub-sectors of education. The teacher professional sub-sector was entrusted to the Canadian Kosovo Educator Development Programme. They performed this function until 2002 when the Ministry of Education, Science and Technology (MEST) was established and took over responsibilities in the sector.

In accordance with the priorities subsequently set by the MEST, donors and providers of the training programmes harmonized their projects and programs (EU EDUCATION SWap, 2011, p. 8 - 9) with the MEST strategies and policies.

Within the IPA financed EU Education SWAp project, MEST, in cooperation with the European Commission, compiled a catalogue of training programs, which was important both for teachers and the MEST, in the process of building the system for teacher professional development and educational leadership. All these programmes have been accredited by the MEST, in accordance with administrative instructions (Cakaj, 2011).

Programs accredited by MEST and offered by different providers are presented in the catalogue describing: the type of program, the provider, duration, beneficiaries, outcomes, content, methodology and certification process. This information was important during the licensing process, where teachers needed to present training programmes they had attended (EU EDUCATION SWap, 2011, p. 9-10). Details of these accredited programmes can be found on the website of the Ministry of Education, the Science and Technology.

This catalogue shows a large number of training programmes on offer. It can be observed that the Kosovo Education Center (KEC) has provided most training; then comes the Center for the Advancement of Education (QPEA); and, the German - Gesellschaft für Internationale Zusammenarbeit (GIZ) etc. Each of the providers mentioned had their training programmes designed based on the interests and teacher professional development needs.

\section{Research Methodology}

\subsection{Research method:}

In this paper we have used a quantitative and qualitative approach and the literature review, statistical analysis and interview techniques. The statistical analyses are a representation of the survey conducted with the teachers of the actual In - Service Teacher Qualification programme. The survey involved 31 attendees of the program, from different education centers in Kosovo.

From the total number of the attendees, 18 or $58 \%$ are female and 13 or $42 \%$ male. The questionnaire contains in total 6 questions.

Quantitative research findings in this paper are results of piloting the $\mathrm{PhD}$ research questionnaire.

Furthermore, the interviews were also conducted with school managements, to get the real reflection directly from the school. They were asked in order to receive their views on the need for teacher professional development, and in regards to the impact of the trainings, especially in regards to the impact of the In - Service Teacher Qualification programme in raising the quality of teaching. The Interview protocol contained a total of 7 questions.

The above mentioned research approach was used to verify the hypotheses, concerning the effects and the role of professional development of teachers, in improving the quality of teaching and the role of the In - Service Teacher Qualification programme in meeting the professional development needs of teachers.

\section{Findings and Discussion}

\subsection{Results of the questionnaires - quantitative analysis}

The questionnaire conducted with the In - Service Teacher Qualification programme attendees, most of whom have been previously following the training programmes mentioned above, was composed from a combination of open-ended and closed factual questions. The questionnaire was designed to verify the attitude of the attendees, about the impact of 
professional development and In - Service Teacher Qualification programme in raising the quality of teaching.

Table No. 1

\begin{tabular}{|c|c|c|c|}
\hline Questions & Yes & No & No answer \\
\hline \multirow{2}{*}{$\begin{array}{l}\text { 2. Have you had a chance earlier to undergo a training programme for professional } \\
\text { development? }\end{array}$} & 21 & 8 & 2 \\
\hline & $68 \%$ & $26 \%$ & $6 \%$ \\
\hline \multirow{2}{*}{$\begin{array}{l}\text { 3. Do you think that professional development (considered that should continue throughout } \\
\text { life), is useful for possession of new knowledge and for raising the quality of work? }\end{array}$} & 28 & 2 & 1 \\
\hline & $90 \%$ & $7 \%$ & $3 \%$ \\
\hline \multirow{2}{*}{ 6. Should the program continue? } & 21 & 3 & 7 \\
\hline & $68 \%$ & $22 \%$ & $10 \%$ \\
\hline
\end{tabular}

\begin{tabular}{|c|c|c|c|c|c|c|}
\hline Questions & 을 & 家 & 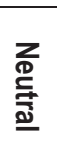 & $\begin{array}{l}\text { 뭉 } \\
\text { 응 } \\
\text { ه }\end{array}$ & 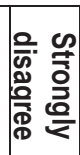 & 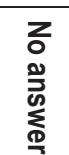 \\
\hline \multirow{2}{*}{$\begin{array}{l}\text { 4. Does the In - Service Teacher Qualification programme provides, raising the } \\
\text { qualifications of teachers and increase the quality of teaching? }\end{array}$} & 14 & 8 & 0 & 3 & 0 & 6 \\
\hline & \begin{tabular}{|l|}
$45 \%$ \\
\end{tabular} & $26 \%$ & $0 \%$ & $10 \%$ & $0 \%$ & $19 \%$ \\
\hline
\end{tabular}

Attendance of professional development trainings: To the question regarding attendance of professional development trainings, as it can be seen from the table, trainings that teachers have followed, are: Step by step, ECDL, studentcentered teaching, trainings for new curriculum, Inclusion, Reading and writing for critical thinking, psychosocial training, training for student evaluation - summative and formative assessment, curriculum for preschool age 3-6 years old, 0-6 preschool standards, provided by KEDP, KEC, USAID, the Tempus project, Basic Education programme etc.

It is clearly noticed a higher participation of teachers in training programmes. The reason that a number of teachers are not involved in these training programs, may be associated with the reflection of the differences between teachers within the school, relying only a number of teachers, or because of the apathy - disinterest of teachers appointed to attend training programs. When looking at the importance of teacher professional development, as well as organizing various training programs, at the international level, seeing motivation for lifelong learning, as important components to the success of teachers in their work with pupils (according to the authors dealing with this issue - see above), there is no doubt that is done on organizing numerous training programs, but also on motivating teachers to attend this training, linking this directly with increased the quality in the classroom. Such a thing regarding teachers motivation, not even happen at national level.

On the other hand, adult education, it is also important at the local level. This relates to the use of the concept, since the Renaissance, when the first schools were opened not only for children but also for adults. Since then, training programs for teachers have been continuously organized.

Benefit of professional development in owning new knowledge: Asked about the benefits of the training programmes, the vast majority respondents claimed that they were happy with the training programmes. Positive answers were given on the grounds that professional development is useful for gaining new knowledge and improving quality of work, because the technical and technological development is rapid, and also because of gaining knowledge about new methodologies. Also, respondents consider professional training necessary and useful at any time and at any age, because as long as one lives, one teaches and needs to develop one's skills. They think that by gaining new knowledge they increase the possibility of professional advancement. Thus, professional advancement creates creativity, delivers results, and offers the opportunity to exchange experiences with colleagues.

By analyzing the question of the teachers benefit, through training programmes, we focus on the opinion of the Albanian author, V. Peshkëpia, who considers the school an institution that deals with repetition of knowledge, but also a place where the received information, serves to solve different problems. In order to achieve this, teachers need to be continuously educated. With regards to that, the approximate opinions of the respondents are reflected, which also consider obtaining information continuously, necessary for the improvement of quality at work, exactly at the time when information technology is being advanced.

The effect of the In - Service Teacher Qualification programme in raising the quality of teaching: Regarding the impact of the In - Service Teacher Qualification programme, in raising the quality of teaching and the qualification of teachers, more positive responses are given (see above).

In the open-ended question, no. 5 - "Do you think the In - Service Teacher Qualification programme meets your 
professional development needs, or you should continue with attending other courses" $15 \%$ of the respondents believe that the program has its values, but as knowledge has no limits, other trainings should also be organized in order to exchange experiences with others. A small number of the respondents believe that the programme should continue, but only for ages $25-40$ years. There are some respondents (30\%) who gave negative responses while others, in greater numbers (35\%) gave the answer that the programme completely meets professional development needs. $35 \%$ of the respondents, did not respond at all. All this relates to the importance of lifelong learning and the fact that it is never too late to learn, but the In - Service Teacher Qualification programme, is not the only way to professional development.

Why In - Service Teacher Qualification programme is not considered as the only mechanism to fulfilling the professional development needs of teachers, is a matter that should be treated more! One of the possibilities would be hesitation of teachers to continue the studies in this programme, considering attendance as an imposition, and such a hesitation creates, uncertainty for teachers, considering the programme as excessive. Thus, training programmes (offered by the different organizations) are considered primary sources, where they have acquired new teaching methodologies. And the question arises: Is it offered the qualitative teaching, in the In - Service Teacher Qualification programme, where teachers were able to be equipped with new knowledge? This is an issue that requires further research.

Another view, leads to the idea that raising the qualification and receiving the title "Bachelor" is more important for teachers than the constructive assessment for the quality of teaching that is offered in the programme.

Regarding the continuation of the programme, positive answers are given, for many reasons. Therefore, the programme should continue to learn new things and to recall previously learned things, to maintain the workplace, professional reinforcement. In addition, another reason why the programme should continue is that all teachers should have the opportunity to be part of the programme and, above all, because the programme opens the opportunity for the Master studies.

Three reasons given by respondents - not to continue the programme - are that the age prevents them to acquire new things easily. Also, they consider that the current qualification is enough, and it is not required any additional qualification, which means that there are teachers who think that the experience and knowledge gained in Higher Pedagogical School, are enough to be successful in their work with students.

\subsection{Results of the interviews - Qualitative analysis}

Apart from the quantitative research, interviews were also conducted with 8 school leaders, in the four regional centers of Kosovo, in Pristina, Gjilan, Prizren and Gjakova.

The need and the interest for teacher professional development: From the principals perspective on the need for teacher professional development, the teacher professional development, obviously, is considered as a necessity, either to meet the criteria for the education system reform in general, or to reform the actual learning process, improving the quality of teaching through the use of innovative teaching strategies and fostering students' critical thinking.

It was pointed out that throughout Kosovo, Kosovar teachers have had the opportunity to undergo teacher training (offered by various governmental and non-governmental associations, in support by the MEST). Furthermore, the interest of teachers for professional development and continuous education in the programmes that offer further qualifications for them has been emphasized. The interest differs depending on the teachers' age (younger teachers are more interested). The In - Service Teacher Qualification programme is seen as a necessity, or a must to advance the teacher qualifications, so the interest is added to all ages.

According to the interviewees, interest for professional development is more emphasized for young teachers in cases where they are not obliged. While, despite of age, interest is added, when participating in a formal programme, such as In - Service Teacher Qualification programme is seen as necessary for the advancement of existing qualifications.

The impact of professional development: The responses of the school leaders in regards to the impact of the trainings, especially in regards to the impact of the In - Service Teacher Qualification programme was quite different. Differences in responses are given as follows: "The programme is necessary. Participants in the programme learn new teaching methodologies that should be part of education system reform, because the strategies that were used after the war do not coincide with current strategies. All this determines the rapid development of technology and science". As we can see, the answer given by the head of school in Pristina, differs from that of the school leader in Gjilan, who emphasizes as follows: "The In - Service Teacher Qualification program is very useful, but I don't want to say that teachers qualified in Higher Pedagogical school, are not professional enough. So, I want to be limited in this regard, 
because my personal opinion coincides with the fact that the success of teachers in the classroom depends on their creativity". We received an entirely different response from the school leader of Gjakova region. He said as following: "I think that the In - service Teacher Qualification programme should be analyzed deeply, because is not very successful. And therefore, the programme should be analyzed to see what the results are. This programme has no impact in terms of raising the quality of teaching and the progress is lower than believed".

As we can see, we have three completely opposite response. According to these results the programme loses sustainability, in terms of raising the quality of teacher's performance.

The interviewee expressed that in raising the quality of teaching, affects, the desire and willingness of the teachers in bringing innovation and creativity in the classroom. The teacher professional development programmes offered in the recent years have had a greater impact on raising the quality of teaching. The senior teachers (the ones who have completed two years of Higher Pedagogical School) are taken as an example, which showed to be very active in their work with students, regardless that they are not participants of the programme.

\section{Conclusions}

Regarding the organization of trainings for professional development and the possibility of attending these trainings, the research conducted with Kosovar teachers (who have attended professional development programmes, and also the In Service Teacher Qualification programme) shows that Kosovo has developed a relatively large number of training programmes. These training programmes primarily target innovative and up-to-date practices, including changes in teaching methodology, using new methods and techniques that focus on student-centered teaching, activation of students' critical thinking and so on.

The issue of the importance of professional development on gaining new knowledge and in raising the quality of teaching is considered a necessity of time, because of the dynamic development of technology, and which should occur at any stage and throughout life.

At this point, regarding the positive effect of teacher professional development in increasing quality, the main hypothesis of the paper is verified. This happens through gaining new knowledge through the use of new methodologies in the learning process, improving teacher performance in the classroom, encouraging students' critical and logical thinking towards full and attentive understanding, as well as application of competency-based assessment approach. However, at national level, it is evident the lack of teachers motivation for professional development.

Values of the In-Service Teacher Qualification programme as an element of lifelong learning are incontestable in terms of meeting the needs for professional development. But the organization of continuous training programmes is obligatory, because of the need to be in line with rapid changes that are occurring every day in the education area. The weakness of this program mainly belongs to a number of older teachers, considering this qualification programme as needless for teachers of older ages.

Regarding the verification of the auxiliary hypothesis, it can not be argued that the In - Service Teacher Qualification program, can be considered as proper mechanism and the only way to meet the professional development needs of teachers, but it can be considered more as a good opportunity for advancing the existing qualifications.

An important issue that is worth mentioning is that most of the attendees of the programme consider attending courses in the programme are considered beneficial only as a requirement to maintain the workplace, and not as really needed for their professional development.

Consequently, the organization of training programmes for Kosovar teachers should continue, but also developing strategies to raise awareness of the teacher community, on the importance and role of professional development in raising the quality of teaching. On the other side, the work of the In - Service Teacher Qualification programme, would have to be reviewed, in terms of the courses and teaching methodology.

The research results lead to the view that as training programmes, as well as In - Service Teacher Qualification programme, help updating knowledge, but training programmes are basic mechanism, for the advancement of teaching performance.

Finally, we may conclude that professional development has direct impact on the careers of teachers. This impact relates to the fulfilment of the criteria for reforming the educational system, among other licensing criteria, as well as the changes in the system of teachers' salaries. Actually, the changes in the system of teachers' salaries, are enabled through In - Teacher Qualification Service programm 


\section{References}

Bicaj. A., \& Berisha. F., (2013). Journal of Education Culture and Society. Teacher preparation reforms in Kosovo. Poland. Pro scientia publica.

Bicaj \& Kotori (2013, May). The 1st International Conference on Research and Educatıon - Challenges Toward the Future (ICRAE 2013). In - Service Teacher Training Program - the functioning and challenges. Shkoder, Albania.

Cakaj, I. (2011). Cilesi ne arsim vetem me mesimdhenes profesioniste. Mesuesi i Kosoves. Prishtine.

EU EDUCATION SWap, project. (2011).

Filipovic, D. (1967). Adult education theory and praxis. Rilindja. Beograd.

Hager, P; Haliday, J. (2006). Recovering informal learning - wisdom judgement and community. Springer. The Netherlands.

Hargreaves, A. (2000). Four Ages of Professionalism and Professional Learning. Teacher and teaching: History and Practice.

Hargreaves, A., Fullan. M. (2012). Learning Forward's Annual Conference. Boston, Mass.

Kassworm, C; Hemmingsen, L. (2006).

Kheng, N. S. (2006). An insider perspective of lifelong learning in Singapore: beyond the economic perspective. Durham University.

Knowles, M. S; Holton III, E. F; Swanson, R. A. (2007). Lebenlanges Lernen andragogik and erwachsenenbildung. Elsevier. München.

Koliqi, H. (2013). Historia e arsimit dhe e mendimit pedagogjik shqiptar. Libri shkollor. Prishtinë.

Mayhew, M. J; Wolniak, G. C; Pascarella, E. T. (2007). How educational practices affect the development of lifelong learning in orientations in traditionally aged undergraduate students. USA.

Peshkëpia, V. (2012). Mësimdhënia mësimnxënia raportet e tyre me integrimin evropian. Fan Noli. Tiranë.

Smith, S. M; Pourchot, Th. (1998). Adult learning and development perspectives from educational psychology. Lawrence Erlbaum Associates. Northern Illionis.

V. Zuljan M., Vogrinc, J. (2011). European Dimensions of Teacher Education - similarities and differencies. Ljubljana.

Klashnja, S. (2006). Aftësimi profesional i mësimdhënësve në vendet evropiane. VanBalkom, W,. Mijatoviq, S. (eds.). Aftësimi profesional: Përvoja nga mësimdhënësit për mësimdhënësit. Educator development program.

Salihu, R. (2006).Reforma arsimore dhe aftësimi professional i mësimdhënësve. VanBalkom, W,. Mijatoviq, S. (eds.). Aftësimi profesional: Përvoja nga mësimdhënësit për mësimdhënësit. Educator development program. 
